\title{
Hegemoni Media Massa dalam Novel "Faith and The City (2015)" Karya Hanum Salsabiela Rais dan Rangga Almahendra
}

\author{
Mass Media Hegemony in "Faith and The City" Novel By Hanum \\ Salsabiela Rais and Rangga Almahendra \\ Wafiqotin Nazihah \\ Candra Rahma Wijaya Putra \\ Universitas Muhammadiyah Malang \\ Jl. Raya Tlogomas No.246 Malang, Jawa Timur, Indonesia \\ wafiq.armadyah@gmail.com
}

Riwayat Artikel: Dikirim 7 Januari 2020; Diterima 12 Juni 2020; Diterbitkan 30 Juni 2020

\begin{abstract}
ABSTRAK
Tujuan umum penelitian ini adalah untuk mendeskripsikan pengaruh hegemoni yang berdampak pada kekuasaan dan dialami oleh habitus kelas bawah dalam novel Faith and The City (2015). Pendekatan yang digunakan dalam penelitian ini adalah pendekatan kualitatif dengan metode analisis isi (content analysis) guna mendeskripsikan secara rinci bentuk penguasaan dalam bentuk hegemoni yang ada dalam novel Faith and The City (2015) berkaitan dengan problematika kompleks mengenai kehidupan bersosial. Data dikumpulkan melalui kutipan dan dialog antar tokoh dengan deskriptif yang tersistematis. Hasil penelitian hegemoni media massa yang dialami tokoh terdiri atas struktur sosial yang berdampak pada kekuasaan norma masyarakat dan kekuasaan kelas sosial dalam novel Faith and The City (2015). Hegemoni yang dilakukan oleh tokoh kelas sosial atas kepada kelas sosial bawah berdampak pada kehidupan tokoh lain pada strata yang lebih rendah, sehingga kaum terhegemoni mengalami tekanan bathin dalam kehidupannya meskipun perilaku hegemoni sudah berdasar pada kesepakatan kedua belah pihak. Teknik pengumpulan data peneliti menggunakan teknik simak catat. Hasil analisis novel memuat unsur hegemoni media massa yang berdampak pada kehidupan tokoh lain.
\end{abstract}

Kata kunci: hegemoni, media massa, kelas sosial, masyarakat. 


\begin{abstract}
$A B S T R A C T$
The general objective of this research is to describe the influence of hegemony that affects the power experienced by lower-class habitus in the novel Faith and The City (2015). The approach used in this study is a qualitative approach with a content analysis method to describe in detail the form of mastery in the form of hegemony in the novel Faith and The City (2015) relating to complex problems regarding social life. Data is collected through quotations and dialogues between characters with systematic descriptive analysis. The results of mass media hegemony research experienced by the figures consist of social structures that affect the power of community norms and the power of social classes in the novel Faith and The City (2015). The hegemony carried out by upper social class figures to the lower social class has an impact on the lives of other figures in the lower strata, so that hegemony experieces inner pressure in their lives even though the hegemony behavior has been based on the agreement of both parties. The data collection technique of the researcher used the notes technique. The results of the novel analysis contain elements of mass media begemony that have an impact on the lives of other figures.
\end{abstract}

Keywords: hegemony, mass media, social class, society

\title{
PENDAHULUAN
}

Kodrat manusia sebagai makhluk sosial yang membutuhkan karya seni merupakan bentuk pengaruh dari pemenuhan terhadap naluri keindahan dalam diri manusia. Sifat alami manusia yang tidak bisa lepas dari aspek agama, politik, sosial dan ekonomi menjadi satu kesatuan dalam kehidupan masyarakat. Dari berbagai macam aspek tersebut, banyak sekali problematika yang dihadapi oleh manusia, salah satunya mengenai adanya bentuk dominasi yang terjadi dalam lingkup masyarakat. Kuatnya pengaruh kepemimpinan baik secara moral maupun intelektual sangat berdampak pada kehidupan manusia, sehingga persoalan tersebut akan bisa dijadikan garapan bagi penulis sastra untuk mengungkapkan problematika manusia dalam sebuah karya sastra yang digarapnya.

Ekspresi material (pembentukan karakter) dari pengalaman manusia merupakan cerminan dari terbentuknya sebuah karya sastra (Suryaman, 2010). Ide kreatif tidak akan bisa dipisahkan dari kehidupan sosial, sehingga keberadaan sastra merupakan bentuk dari problematika manusia dalam kehidupan nyata. Sastra bisa menjadi jembatan antara realita dengan imajinasi pengarang, sehingga hal ini dapat membantu menemukan pencerahan mengenai kenyataan hidup yang seharusnya bisa diperbaiki. Karya kreatif manusia yang di dalamnya disajikan sebuah seni membutuhkan pengolahan 
bahasa yang baik agar menjadikan daya tarik tersendiri bagi pembaca untuk mengetahui gambaran kehidupan manusia.

Asumsi dasar penelitian ini berawal dari menariknya permasalahan yang diungkapkan dalam novel Faith and The City (2015) karya Hanum Salsabiela Rais dan Rangga Almahendra. Novel ini menceritakan mengenai kondisi kehidupan tokoh yang terjebak konflik kekuasaan dalam unsur hegemoni pada struktur sosial yang berdampak pada kekuasaan norma masyarakat dan kelas sosial. Bentuk hegemoni ini berdampak pada permasalahan yang terjadi antara kelas sosial atas dan kelas sosial bawah dalam sebuah stasiun televisi yang hanya memikirkan mengenai rating and share tanpa mempedulikan perasaan dan hati nurani dari karyawan-karyawannya serta narasumber yang dihadirkan untuk dikuak permasalahan-permasalahan pribadinya.

Permasalahan yang disampaikan dalam novel Faith and The City (2015) berkaitan erat dengan hegemoni terhadap kelompok tertentu melalui sebuah persetujuan. Menurut pandangan Gramsci, bentuk kekuasaan terbagi menjadi 2, yakni hegemoni dan dominasi (perebutan kekuasaan dengan bentuk kekerasan). Dalam hal ini, hegemoni pada novel faith and the city telah berlandaskan pada kesepakatan, namun tetap saja dari kesepakatan itu berdampak pada tekanan batin yang dialami tokoh. Dari kondisi tersebut, tampak bahwa hegemoni sangat mempengaruhi kehidupan pribadi seseorang meskipun tidak ada perlakuan melukai secara fisik. Mengenai kondisi hegemoni yang dialami tokoh, novel karya Hanum dan Rangga ini menyelipkan sebuah upaya penyelesaian konflik dari perlakuan hegemoni yang terjadi, sehingga pembaca dapat mengambil pelajaran dari karya sastra yang telah ditulis tersebut untuk direalisasikan dalam dunia nyata.

Penelitian-penelitian yang menganalisis mengenai hegemoni pernah dilakukan sebelumnya, penelitian pertama yang relevan dilakukan oleh Hatmoko (2014) dengan judul Hegemoni Moral Nyai Kartareja terhadap Srintil dalam Novel Jantera Bianglala Karya Ahmad Thohari : Kajian Hegemoni Gramsci. Dalam penelitian tersebut difokuskan pada adanya faktor-faktor penyebab terjadinya hegemoni moral dan praktik hegemoni moral, namun pada penelitian hegemoni moral tersebut hanya fokus pada dua tokoh yang saling menghegemoni, sehingga dampak dari perlakuan tersebut juga hanya diterima oleh kedua tokoh saja tanpa disertai bentuk peleraian dari hegemoni yang dilakukan.

Penelitian lain yang membahas mengenai hegemoni dilakukan oleh Wijangkangka (2008) dengan judul penelitian Analisis Hegemoni Kekuasaan dalam Novel Pabrik Karya Putu Wijaya. Penelitian tersebut hanya terfokus pada aspek hegemoni yang terjadi atasan dan bawahan tanpa menimbulkan konflik sepihak, walaupun sama-sama menggunakan teori hegemoni, namun penelitian ini lebih mengaitkan dalam tataran hegemoni kekuasaan kerja dengan pemaksaan kerja di luar jam kepada para pembantu dengan insentive power untuk membujuk para buruh agar mereka dapat dikuasai oleh pemegang 
kekuasaan, sehingga hal tersebut berpengaruh terhadap kehidupan tokoh meskipun masih belum ada penjelasan mengenai upaya dalam penyelesaian konflik.

Dalam kedua penelitian yang dilakukan peneliti sebelumnya, fokus penelitian pertama relevan dengan bentuk hegemoni antara dua orang dalam tataran moral, sedangkan fokus penelitian kedua mengarah pada hegemoni yang dilakukan pada sekelompok orang dalam menjalankan pekerjaan yang dilakukannya. Kedua penelitian yang dikaitkan dengan penelitian yang ditulis oleh peneliti merupakan bentuk hegemoni dalam kehidupan masyarakat yang dikembangkan berdasarkan teori sosiologi sastra yang mampu dijadikan rujukan untuk pembelajaran dalam menjalani kehidupan dalam lingkup sosial di kehidupan nyata.

Pengembangan dari masalah hegemoni yang pernah dilakukan oleh peneliti sebelumnya. Faith and The City (2015) ini salah satu novel seputar hegemoni yang tetap menarik untuk dikaji, penjabaran dari hegemoni yang dilakukan oleh kelas sosial atas kepada kelas sosial bawah mengarah pada penyelesaian konflik oleh sebuah kesatuan dari kaum atas dan kaum bawah sendiri, sehingga tampak peleraian yang menguntungkan antara kedua belah pihak. Upaya penyelesaian konflik juga di desain dengan bahasa yang sarat makna sehingga memudahkan pembaca memahami alur hegemoni yang bisa dikaitkan dalam lingkungan masyarakat saat ini. Berdasarkan hal tersebut, tujuan penelitian (1) mendeskripsikan struktur sosial yang terdapat dalam novel Faith and The City (2015) (2) mendeskripsikan hegemoni kelas sosial dan norma masyarakat dalam novel Faith and The City (2015).

\section{Hegemoni Media Massa}

Media massa merupakan salah satu alat yang digunakan dalam penyampai pesan kepada khalayak umum menggunakan alat-alat komunikasi mekanis. Berdasarkan hal tersebut, penggunaan media massa seharusnya bersifat netral, namun pada kenyataannya setiap media massa memiliki kepentingan tersendiri dalam untuk menyebarkan dan menciptakan hegemoni di segala informasi baik mengenai konten maupun narasumber langsung.

Menurut teori hegemoni Gramsci, kelompok dominan dalam masyarakat yang dikenai sasaran hegemoni bukan kelas ekslusif penguasa, melainkan kelas pekerja yang telah menciptakan negoisasi sebelum adanya hegemoni. Artinya, kedua pihak yang terlibat dalam konsep hegemoni telah sama-sama menyetujui akan segala keputusan yang telah dibuat meskipun dalam pelaksanaannya masih memunculkan suatu problem walaupun hanya dapat dirasakan oleh individu masing-masing.

Faktor ideologi dan politik merupakan faktor utama adanya hegemoni media massa dalam salah satu alat komunikasi (Lestari, 2017:4). Penekanan ini mengarahkan pada teori hegemoni dalam media massa yang telah 
mendapat persetujuan oleh kedua belah pihak, namun persetujuan tersebut tetap berdampak negatif dalam diri seseorang (pihak terhegemoni). Konsep dalam balutan hegemoni media massa selalu dicekoki dengan bonus-bonus yang banyak sebagai bentuk sumbangsih keberterimaan mereka melejitkan nama media massa yang sedang digarapnya hanya bisa dinikmati dengan adanya keterpaksaan.

Khalayak umum sebagai objek penerima konsep hegemoni dalam suatu media massa akan menerima semua informasi dari media ke dalam pikirannya, hal ini sebagai bentuk suatu kepercayaan terhadap media yang seharusnya konsep percaya ini bisa dijalankan sepenuhnya. Dalam hal ini, hegemoni dalam pelaksanaannya tidak menggunakan kekuatan fisik dalam menguasai pola pikir khalayak umum, melainkan dengan mematuhi segala sesuatu yang telah ditetapkan dalam suatu kelas sosial atas tanpa kekerasan meskipun menyalahi (Simon, 2004:56).

\section{METODE}

Pada penelitian ini, metode kualitatif digunakan dengan membaca dan menganalisis makna yang terkandung dalam novel (Syarifudin, 2019:18). Artinya, metode kualitatif digunakan untuk mendapatkan makna mendalam dari novel yang dikaji dengan pencarian data yang tersirat dari data yang tampak untuk selanjutnya digabung dengan pembahasan yang terfokus pada objek sasaran penelitian. Sumber data dalam penelitian ini adalah novel berjudul Faith and The City (2015) karya Hanum Salsabiela Rais dan Rangga Almahendra. Novel tersebut diterbitkan oleh PT. Gramedia Pustaka Utama pada tahun 2015 yang terdiri atas 224 halaman.

Penelitian mengenai hegemoni dalam novel Faith and The City (2015) karya Hanum Salsabila Rais dan Rangga Alamahendra ini menggunakan metode analisis isi (content analysis). Penelitian ini mendeskripsikan secara rinci bentuk penguasaan dalam bentuk hegemoni yang ada dalam novel berkaitan dengan problematika kompleks mengenai pentingnya menghargai seseorang yang berharga dalam hidup kita dengan ikhlas tanpa mengharap imbalan dalam bentuk apapun, sehingga penelitian ini memfokuskan pada kutipankutipan atau dialog yang mengarah pada pembahasan mengenai dominasi yang telah disetujui namun masih mendapatkan dampak negatif dalam kehidupannya.

Teknik pemaparan isi dilakukan secara objektif dan sistematis yang memperlihatkan pada makna konstektual. Deskripsi secara menyeluruh mengenai dominasi bisa dijadikan rujukan sebagai pembelajaran mengenai pentingnya menghargai orang lain. Dalam penelitian ini, langkah-langkah yang digunakan untuk menganalisis data meliputi (1) Membaca serta memahami isi yang ada dalam novel Faith and The City (2015) (2) menggali permasalahan dominasi yang terjadi dalam novel Faith and The City (2015) (3) mendeskripsikan permasalahan dominasi yang diurutkan per aspek (4) 
mengelompokkan permasalahan dominasi atau kekuasaan yang didapat berdasarkan aspek yang ditemukan (5) mengekplorasi lebih dalam berdasarkan kutipan dan dialog yang mengarah pada aspek-aspek hegemoni (6) membuat kesimpulan.

\section{HASIL DAN PEMBAHASAN}

Fenomena yang terjadi dalam novel Faith and The City (2015) berkaitan langsung dengan konsep hegemoni yang mengacu pada tingkat stabilitas sosial. Dalam novel ini, hegemoni media massa muncul pada tataran atasan dan bawahan (karyawan dan narasumber) yang ada di salah satu stasiun televisi. Dalam kemunculan media massa ini, kelas bawah aktif mendukung segala bentuk ide, nilai dan tujuan yang menyatukan mereka dalam kekuasaan yang ada (Wijakangka, 2008). Artinya bahwa dalam hegemoni yang didapat dari sebuah media massa menyatakan suatu bentuk pengaruh terhadap kehidupan tokoh yang dikemas dalam bentuk persetujuan antara kedua belah pihak.

Bentuk hegemoni yang diwujudkan dalam novel Faith and The City (2015) lebih terfokus pada pemaksaan kerja di luar jam dan menghalalkan segala cara dengan mengeksploitasi narasumber tanpa memikirkan hati nurani untuk mendapatkan rating and share demi menghasilkan bonus-bonus besar dalam gaji yang diberikan pada karyawannya. Oleh karena itu, pengkajian mengenai paparan hegemoni dalam suatu pekerjaan (media massa) perlu ditonjolkan lebih dalam sebagai bentuk pemahaman mengenai strata sosial yang saat ini masih belum diwujudkan secara baik.

\section{Struktur Sosial Dalam Novel Faith and The City}

Struktur sosial dalam kehidupan masyarakat didefinisikan sebagai perilaku berulang yang berkaitan dengan hubungan antarkelompok dan antarindividu yang terjadi dalam suatu tatanan masyarakat. Berkenaan dengan hal ini, akan adanya penyesuaian perilaku yang berakibat pada perbedaan stratifikasi dan strata sosial sehingga membentuk kelas-kelas sosial dalam suatu masyarakat. Dalam novel Faith and The City (2015), struktur sosial membentuk menjadi kelas sosial atas dan kelas sosial bawah dengan sebuah hegemoni melalui persetujuan kedua belah pihak.

Kelas sosial bawah dalam novel Faith and The City (2015) adalah para karyawan GNTV dari Indonesia yang mengabdikan diri bekerja di New York. Kesempatan bekerja ini menjadi peluang besar bagi karyawan untuk mendapatkan bonus dan gaji tinggi meskipun melalui tuntutan berat dari manager GNTV. Selain itu, GNTV ini merupakan salah satu media massa terpopuler di New York sehingga lembar kontrak kerja di GNTV sangat berpengaruh besar jika ingin memiliki pengalaman yang menantang. 
Pengeksploitasian tidak hanya dialami oleh karyawan-karyawannya saja, melainkan juga narasumber yang dihadirkan dalam suatu acara garapan dari GNTV.

Kelas sosial atas dalam novel Faith and The City (2015) merupakan manager dan atasan yang mengatur produksi dari media massa GNTV, tuntutan untuk selalu memiliki rating dan share yang tinggi untuk mendapatkan grade adalah visi misi dari GNTV, kemerosotan satu hari di GNTV mengakibatkan kerugian dalam media, maka manager dari GNTV selalu menuntut karyawannya bekerja lebih dengan tanpa kenal waktu dan tanpa memikirkan hati nurani narasumber atau sasaran berita yang akan disampaikan dengan iming-iming gaji dan bonus yang besar serta surat kontrak perjanjian kerja dari GNTV.

\section{Kekuasaan Yang Diberi Atas Kelas Sosial}

Sistem kedudukan dalam tataran masyarakat mengalami penggolongan sosial yang membedakan strata serta kedudukan mereka dalam sebuah masyarakat. Berdasarkan hal tersebut, tidak menutup kemungkinan sistem kelas sosial masih sering terjadi dalam dunia kerja (atasan dan bawahan). Pemimpin yang berorientasi pada target serta menuntut perfect sesuai prosedur adalah pemimpin yang transaksional (Rosiana, 2015). Artinya, dalam hal pekerjaan yang dinilai hanya sebuah rating and share yang dicekoki dengan bonus-bonus untuk mendapat kesenangan dalam menjalani pekerjaannya tanpa memperhatikan hati nurani.

"Aku baru saja membeli sabam GNTV minggu lalu. Dan aku baru sadar acara Insight Muslims ini hanya mengincar kehidupan pribadiku dan Azima Hussein. Mereka tidak benar-benar membuat acara ini dari hati. Meskipun pada akbirnya episode demi episode memberi mereka iklan jutaan dolar, tapi visi acara ini tidak benar-benar mengangkat inspirasi muslim, melainkan banya mengeksploitasinya." (bal.195)

GNTV, salah satu media terbesar di New York yang mengalami perkembangan pesat setelah mengeksploitasi narasumber yang sengaja dihadirkan dalam media massanya untuk menghasilkan share and rating. Karyawan GNTV merupakan golongan kelas bawah yang membutuhkan kesempatan kerja sehingga mereka hanya bisa menuruti kemauan para atasannya untuk mengerjakan segala sesuatu meskipun tidak mempedulikan mengenai keprivasian dari narasumbernya sendiri.

Hegemoni kelas sosial ini tampak pada pekerjaan yang dilakukan oleh karyawan GNTV, dengan dicekoki bonus yang besar dan surat kontrak kerja, mereka melawan rasa persaudaraannya untuk menguak segala privasi yang dimiliki oleh narasumber. Ketidakpedulian mengenai hati nurani orang-orang yang tersakiti dari wawancara tersebut tidak menyurutkan para karyawan untuk bekerja. Selain itu, ancaman dari atasan apabila kerjanya tidak sesuai target juga menumbuhkan ketidakberanian para karyawan memanipulasi 
berita yang telah digarap oleh media massa tempatnya bekerja demi meningkatnya rating dan share.

"Come on, Azima! Cry! Cry! Cry! Helen, ask her about her mother! Hyacinth! About her father's death!" Cooper berteriak-teriak sendiri di ruang Holy Room. I a sengaja tidak ingin menampakekan diri di depan narasumber pagi ini. Ia percayakan semua ke anak buahnya yang sudah dicekoki mantra rating dan share. (bal.191-192)

Menjadi narasumber dalam sebuah media massa terkenal merupakan suatu bentuk penghormatan tersendiri, namun akan berbeda jika dalam penghormatan tersebut diselipkan suatu bentuk hegemoni untuk mengungkap segala bentuk keprivasian dalam kehidupan narasumber yang dihadirkan untuk diliput di suatu media massa. Hal tersebut tentu suatu bentuk hegemoni media massa yang mendasarkan pada kelas sosial untuk mendapatkan keuntungan dari salah satu pihak meskipun telah melalui persetujuan.

Pagi itu Hanum menunggu Cooper di ruang Holy Room. Ia merapal doa-doa sebelum bertemu dengan Cooper. Ia juga menghafal bagaimana menyampaikan permohonan maafnya dalam bahasa inggris yang meyentuh hati. Terakbir dia akan mengatakan, bahwa episode variety show yang dibuatny a dulu bisa diputar ulang untuke mengisi live hari ini. I a sudah menyiapkan data responden dan survei dari Tivy, babwa rerun episode variety show miliknya bisa mengungguli rating dan share TV lain pada saat yang sama (bal.184)

Dominasi yang terjadi di antara kelas sosial atas dan bawah menjadi permasalahan signifikan dalam penerapan sebuah aspek hegemoni pekerjaan, dalam novel Faith and The City (2015) hegemoni terletak pada karyawan yang menjadi pihak kelas sosial bawah senantiasa menuruti segala apa yang diperintahkan oleh atasannya meskipun bertentangan dengan hati nuraninya demi mendapatkan suatu bonus yang telah dijanjikan. Ketidakberanian membantah segala peraturan yang sudah digagas oleh atasan membuat karyawan GNTV memiliki prinsip kesempurnaan dalam pekerjaannya meskipun melalui berbagai cara, kekeliruan dalam bekerja merupakan kesalahan terbesar dalam media massa ini.

\section{Kekuasaan Berdasarkan Norma Masyarakat}

Suatu kelompok dalam sebuah masyarakat tentu memiliki aturan yang harus dijalankan. Setiap daerah memiliki aturan atau panduan hidup yang berlaku di masyarakat dengan sistem yang berbeda-beda. Dalam tataran pengaplikasian norma masyarakat, seseorang dituntut untuk mempunyai nilai yang mendatangkan kemakmuran bagi masyarakat sebagai suatu kualitas yang dimiliki seseorang dalam kelompok tertentu (Parnomo, 1995:5). Aturan ini menjadi segala sesuatu yang wajib dilaksanakan agar mendapatkan 
keseimbangan hidup di suatu daerah tertentu, meskipun dalam adaptasi mengenai norma masyarakat ini membutuhkan waktu yang cukup lama.

Menjadi kota yang sangat hedonis, masyarakat New York selalu memanfaatkan waktu dengan sebaik-baiknya. Waktu yang diibaratkan dengan uang mampu memanipulasi kehidupan masyarakat yang terpaku pada kehidupan duniawi. Target dan keunggulan selalu menjadi incaran masyarakat, tak terkecuali hal ini menjadi budaya dalam suatu perusahaan media massa GNTV yang dipimpin oleh Andy Cooper, sang jurnalis terkenal di kota New York. Hal ini tentu sangat berbeda dengan kota-kota lain di luar Amerika Serikat terutama Indonesia.

New york city ini sangat hedonis, denyut aktivitas sudah dimulai bersamaan ketika orang saleh memulai tahajudny a di sepertiga malam terakbir. Bedanya pagi buta itu orang saleh membasuh jowsanya untuk bertekuk lutut pada penciptanya, sementara kaum bedon membasuh badannya alias mandi untuk. berkhidmat pada nafsunya. (hal.74)

Karyawan GNTV melakukan pekerjaannya sejak pagi buta, aktivitas ini dimulai sedini mungkin hanya untuk mengejar share dan rating yang memenuhi target. Menjajaki dunia baru dengan penuh tekanan tidak membuat Hanum, pekerja asal Indonesia ini mundur dari pekerjaannya. Ia berusaha keras memperoleh keinginannya dan tidak menyia-nyiakan kesempatan selama di New York. Walaupun tekad yang dimiliki sangat kuat, di suatu waktu Hanum merasa memiliki banyak perubahan negatif yang terjadi dalam dirinya terutama kepada suaminya. Hidup di Negara orang dengan norma yang berbeda tentu harus dipenuhi dengan perjuangan agar bisa beradaptasi dalam waktu yang singkat.

"Hei! Kamu wanita bercadar! Belanjaanmu banyak sekali. Bisa lama sekali nanti. Kamu tunggu, ya!" sentak tommy pada wanita bercadar. Tommy kemudian melibat pria bertato di belakang perempuan bercadar itu. (hal.109)

Menjadi seorang minoritas di suatu Negara tentu membutuhkan keterkaitan lebih untuk bisa memahami karakter, sikap dan keberterimaan masyarakat mayoritas terhadap kehadiran masyarakat minoritas dalam suatu lingkungan tertentu. Media massa GNTV yang mengangkat tema mengenai keislaman dengan ide yang dicetuskan oleh Hanum membuat suatu acara dalam bentuk Social Experiment. Acara ini didesain di sebuah Mall yang menghadirkan wanita bercadar untuk membeli sesuatu, dengan penampilan yang bercadar, GNTV ingin melihat sejauh mana kepedulian orang-orang sekitar khususnya pegawai mall dalam melayani wanita bercadar ini.

Perempuan bercadar itu melihat selurub kamera pengawas. Ia was-was rencana ini tidak berbasil. Ia kemudian mengedarkan pandangan pada pria berotot di belakangnya. (bal.109) 
Tuntutan dari atasan mengenai acara yang sedang digarapnya (insight muslim) membuat karyawan GNTV terjun langsung ke lapangan untuk melihat reaksi orang-orang terhadap wanita berhijab dan bercadar. Karyawan merasa takut karena diawasi oleh sang atasan lewat kamera pengintai pada saat eksekusi. New york memiliki masyarakat yang minoritas terhadap islam, sehingga ide yang dicetuskan oleh Hanum terhadap Social Experiment ini harus menaikkan share dan rating dalam GNTV. Berbagai ancaman dari Andy Cooper mengenai ketidakberhasilan acara ini selalu mengintai pikiran para karyawan di GNTV. Maka dari itu, berbagai upaya harus terus dilakukan untuk bisa menaikkan share dan rating serta mendapatkan bonus yang banyak dari sang bos.

Dalam pelaksanaan hegemoni media massa yang dilakukan kepada para narasumber GNTV memiliki aspek kekerasan simbolik, kekerasan ini menekankan pada makna, logika, dan keyakinan yang mengandung bias tetapi secara halus dan samar dipaksakan kepada pihak lain sebagai sesuatu yang benar (Fashri, 2007). Artinya, kekerasan simbolik media massa memengaruhi cara berpikir, cara kerja dan cara bertindak. Oleh karena itu, dalam praktik kekerasan simbolik tidak ada korban luka fisik secara langsung. Meskipun demikian, rasa tertekan akan dirasakan oleh penerima kekerasan simbolik, salah satunya kekerasan simbolik dalam media massa.

Di Era modernisasi, wartawan dihimbau menjaga dan melindungi privasi narasumber terutama anak adalah upaya untuk menghormati pengalaman tarumatis narasumber melalui teks berita, gambar, video atau lain-lain. Diharapkan untuk tidak memproduksi program yang merusak anak (Pribadi, 2016). Konsep kekerasan simbol menggiring kita ke arah sebuah mekanisme sosial, yang di dalamnya relasi komunikasi saling bertautan dengan relasi kekuasaan. Hal ini dimaksudkan agar semua privasi yang tidak ingin diketahui publik bisa dijaga dengan baik.

Dalam novel Faith and The City (2015). Media massa GNTV memiliki kekuasaan untuk mempekerjakan karyawan dengan mengambil keuntungan lebih, misal dalam hal kekerabatan dan lain sebagainya. GNTV mengambil karyawan yang bisa dieksploitasi untuk mendekati target-target narasumber yang akan diulik privacynya berkenaan dengan Insight Muslim yang sedang dihadirkan dalam acara GNTV pada episode ini. Tuntutan kerja di luar jam juga dipergunakan oleh media GNTV untuk mengejar target yang diinginkan, dengan iming-iming bonus yang tinggi dan pangkat, karyawan GNTV melakukan pekerjaannya tanpa mempedulikan perasaan orang-orang sekitar.

"Hentikan membajak nama Islam, muslim, untuk obsesimu sendiri! Hentikan! Pernah enggak kamu berpikir, kenapa wartawan seperti kamu dipekerjakan oleh... "Rangga tersekat. Ia baru saja salab omong. (bal.171)

Sebuah sistem kekuasaan cenderung untuk melanggengkan posisinya yang dominan dengan cara mendominansi media komunikasi, bahasa yang digunakan di dalam berkomunikasi, makna-makna yang dipertukarkan di 
dalam komunikasi serta interpretasi terhadap makna-makna tersebut. Bentuk eksploitasi yang dihadirkan dalam media massa kepada narasumber GNTV menggunakan sistem dengan dicerca berbagai macam pertanyaan. Dari pertanyaan itulah, setiap privasi diulik agar menimbulkan gejolak bathin (menangis) untuk menaikkan share dan rating.

"Tentang Insight Muslims. Tentang rencanaku mendatangkanmu dan Ažima Hussein esok lusa. Aku tabu kau sudah menolak untuk diwawancarai. Tapi ini demi... " (bal.170)

Norma masyarakat dalam hegemoni media massa sudah tidak lagi memperhatikan aspek persaudaraan. Di negara yang terkenal hedonis ini, Hanum, salah satu karyawan GNTV mengeksploitasi sahabatnya sendiri demi mengadaptasikan diri dalam pekerjaan yang telah ditekuninya. Sahabat Hanum (Azima) tidak bisa menolak, namun di sisi lain dia sudah mengetahui kebobrokan GNTV dalam mengeksploitasi narasumber yang dihadirkan untuk menjadi narasumber. Hal ini membuat boomerang bagi persahabatan keduanya yang diakhiri dengan pembelian saham GNTV oleh pengusaha kaya agar media massa tidak lagi dijadikan sebagai alat kekuasaan yang hanya menguntungkan satu belah pihak.

Berdasarkan analisis di atas, keberadaan hegemoni dalam media massa mempengaruhi hubungan seseorang dengan orang lain dalam hidupnya secara tidak langsung. Keterkaitan ini seiring dengan proses seseorang mencari pengetahuan atau ilmu baru dengan keharusan mengikuti budaya dan peradaban baru dalam tataran sosial tertentu (Nurhadi, 2019:102). Artinya, keterlibatan seseorang dalam perlakuan hegemoni dalam suatu media massa karena adanya keinginan yang mengarah pada aspek ketercapaian suatu tujuan dalam hal yang berkaitan dengan kenaikan roda kehidupan dalam dunianya.

\section{KESIMPULAN}

Konsep hegemoni di New york, kota terpadat di Amerika Serikat yang dikenal sebagai kota hedonis ini mengganggap bahwa orang harus mencari kebahagiaan sebanyak-banyaknya, termasuk dalam masalah pekerjaan. Hal ini menjadi salah satu pelopor media GNTV untuk menjalankan aksinya mengeksploitasi karyawan maupun narasumber. Namun di sisi lain, pihak yang terhegemoni juga menginginkan kebahagiaan dengan menyetujui segala pengaruh yang diberikan oleh GNTV dengan dicekoki bonus-bonus yang besar.

Kekuasaan kelas sosial atas terhadap kelas sosial bawah dan kekuasaan yang disebabkan oleh norma masyarakat ini menimbulkan berbagai macam problematika. Problematika tersebut disadari oleh kelas sosial bawah namun masih dianggap sebagai salah satu prestise yang memberikan keuntungan 
dalam kehidupannya. Hal tersebut memberikan keluasan oleh kelas sosial atas menjalankan aksinya demi kenaikan media massa yang sedang digarapnya, baik itu berupa share maupun rating yang dapat meningkatkan keuntungannya.

Pengaruh yang ditimbulkan dari hegemoni yang terjadi dalam media massa ini menyebabkan reputasi interaksi mereka dengan orang-orang sekitar merenggang. Berdasarkan pemahaman tersebut, orang-orang yang menjadi korban dari konsep hegemoni yakni keluarga dari karyawan dan narasumber dari stratifikasi kelas sosial bawah memberikan seumbangsih dengan berbagai pemahaman untuk mengubah sistem hegemoni yang diterapkan oleh GNTV, dengan membeli saham perusahaan agar bisa diambil alih.

\section{DAFTAR PUSTAKA}

Fashri, Fauzi. (2007). Penyingkapan Kuasa Simbol. Yogyakarta: Juxtapose.

Hatmoko, Mahadi Dwi, dkk. (2014). Hegemoni Moral Nyai Kartareja terhadap Srintil dalam Novel Jantera Bianglala Karya Ahmad Thohari : Kajian Hegemoni Gramsci. Jurnal Sastra Indonesia, 3(1).

Lestari, Lilis. (2017). Hegemoni Kekuasaan dalam Novel Negeri di Ujung Tanduk Karya Tere Liye (Pendekatan Teori Hegemoni Antonio Gramsci). Universitas Negeri Makassar.

Nurhadi, Ardhian, dkk. 2019. Analisis Unsur Semiotika dalam Naskah Drama "RT Nol RW Nol" Karya Iwan Simatupang. Jurnal Lensa: Kajian Kebahasaan, Kesustraan, dan Budaya. Vol. 9 No.1.

Parnomo. (1995). Nilai dan Norma Masyarakat. Jurnal Filsafat. https://doi.org/10.22146/jf.31608.

Pribadi, Farid. 2016. Kekerasan Simbolik Media Massa (Kekerasan simbolik dalam pemberitaan kasus peredaran video asusila di media massa online: kajian sosiologi komunikasi). Jurnal Sosiologi Pendidikan Humanis. Vol. 1 No. 2.

Rosiana, Debby. (2015. Pengaruh Persepsi Gaya Kepemimpinan Atasan Terhadap Motivasi Berprestasi Bawahan (Studi Pada Karyawan BCA Kantor Cabang Alam Sutera). Jurnal Psikologi Esa Unggul. Vol. 13 No 2. Simon, Roger. 2004. Gagasan-gagasan Politik Gramsci. Yogyakarta: Pustaka Pelajar.

Syarifudin, Frisilia. 2019. Channel sebagai Representasi Modal Simbolis dalam Novel "The Devil Wears Prada" Karya Lauren Weisberger. Jurnal Lensa: Kajian Kebahasaan, Kesustraan, dan Budaya. Vol. 9 No.1. 
Suryaman, Maman. (2010). Pendidikan Karakter melalui Pembelajaran Sastra. Jurnal Ilmiah Pendidikan, 10(3), 112-126.

Wijakangka, Agga Ramses. (2008). Analisis Hegemoni Kekuasaan dalam Novel Pabrik Karya Putu Wijaya. Jurnal Artikulasi, 5(1). 